INTERNATIONAL JOURNAL OF RESEARCHES IN BIOSCIENCES, AGRICULTURE AND TECHNOLOGY

(c) VISHWASHANTI MULTIPURPOSE SOCIETY (Global Peace Multipurpose Society) R. No. MH-659/13(N) www.ijrbat.in

\title{
MOLECULAR PHYLOGENETIC RELATIONSHIPS IN GENUS SOLANUM (SOLANACEAE) USING NON-CODING DNA SEQUENCES
}

\author{
Topale Mayuri P, Gawande Prashant A and Khanday Ashiq H. \\ Laboratory of Molecular Systematics \\ Department of Botany, SantGadge Baba Amravati University, Amravati \\ mayuri5265@rediffmail.com, prashantagawande@yahoo.co.in
}

\begin{abstract}
:
Genus Solanum is the most species rich genus in the family Solanaceae with many economically important crop plants like eggplant (Solanum melongena), potato (Solanum tuberosome L.) and tomato (Solanum lycopersicum). Within Solanum, subgenus Leptostemonum (Dunal) bitter is the most species rich clade. Use of molecular data has greatly transformed the approach of plant systematic within this complex genus. In present study molecular phylogenetic study of subgenus Leptostemonum was done on the basis of sequence data of trnL-trnF non-coding region. The molecular data set revealed two major clades in the dendogram. First clade was represented by species from subgenus Leptostemonum, whereas second clade clustered all the Potatoe species forming a clear out-group. trnL-trnF sequence proved to be supportive in inferring the species level relationship within genus Solanum.
\end{abstract}

Keywords: Solanum, Leptostemonum, trnL-trnF

\section{INTRODUCTION:}

Amongst over 90 genera under Solanaceae (Vorontsova and Knapp, 2012) genus Solanum is the largest genus within this family. Nearly half of the species contributed under this family are from the genus Solanum and show phenotypic variation particularly in vegetative features. Giant and diverse genus containing more than 1400 species distributed in temperate and tropical zones in the world (Aubriot, et. al., 2016), has always remained as an important study area for scientists as it includes economically important crop plants like eggplant (Solanum melongena), potato (Solanum tuberosome L.) and tomato (Solanum lycopersicum). This genus is often referred as "spiny solanum" because of its distinguishing characters of presence of sharp epidermal prickles on leaves and stem in most of the species. Within Solanum, subgenus leptostemonum (Dunal) bitter is the most species rich clade and have been identified since the time of Linneaus, (1753). This group contains nearly 350450 species (Bohr, 2005) comprising almost one third of the genus Solanum (Levin et al., 2006).

Use of molecular data has greatly revolutionized the approach of plant systematics and has led to new insights of phylogenetic studies between closely related species. Non-coding regions have faster rates of evolution; hence these loci can be used as markers to resolve phylogeny at lower taxonomic level, and to study evolutionary relationship (Taberlet, et al., 1991; Holt, et al., 2004). Among the non-coding regions studied in chloroplast genome, the intron of the trnL (UAA) and intergenic spacer of the trnL-trnF (GAA) are suitable for phylogenetic study from intra-species to interfamily level (Bakker, et al., 2000; Fukuda, et al., 2001). trnLtrnFintergenic spacer was used many times to resolve phylogeny amongst closely related species. A combined data set of trnL-F intergenic spacer and trnN intron was used to infer species level phylogeny from of species belonging to section lasiocarpa of genus Solanum (Bohs, 2004). Using a revised molecular data from waxy gene and chloroplast trn $\mathrm{T}-\mathrm{F}$ region, including the $\operatorname{trn} \mathrm{T}-\mathrm{L}$ and trnL-F intergenic spacer regions it was confirmed that African species S. vespertilio and S. lidii species are phylogenetically associated with Solanum lineages (Anderson et al., 2006). Present study deals with phylogenetic analysis of some species from genus Solanum on the basis of trnL-F intergenic spacer sequence collected within Maharashtra State.

\section{METHOD AND MATERIAL:}

Sampling: Species included under genus Solanum, subgenus Leptostemonum were taken into account for present study. It included wild species such as Solanum anguivi, Solanum khasianum, Solanum macranthum, Solanum virginianum and cultivated 
species Solanum melongena (Sungro No. 801). All these species were collected from various geographical regions of Maharashtra state. Outgroup taxa included are from the subgenus Potatoe. Four taxa from this outgroup are Solanum muricatum, Solanum seaforthianum, Solanum tuberosum, Solanum bulbocastanum and their sequences were obtained from Genbank database (Table 1). Outgroups were chosen to represent a variety of diverse Solanum clades.

DNA analysis: Total genomic DNA was extracted from fresh plant leaves and was further used for amplification reaction. trnL-Fintergenic spacer region was amplified using primers trnL- 5'GGTTCAAGTCCCTCTATCCC 3 ' and trnF5'ATTTGAACTGGTGACACGAG 3'. Total 20 $\mu 1$ of PCR reaction mixture contained $3 \mu \mathrm{l}$ template DNA (30$50 \mathrm{ng}), 3 \mu \mathrm{l}$ of $10 \mathrm{X}$ DreamTaq Green Buffer with $20 \mathrm{mM} \mathrm{MgCl} 2$ (Fermentas), $1 \mu \mathrm{l}$ of $25 \mathrm{mM} \mathrm{MgCl} 2$ (Fermentas), $0.8 \mu 1$ of $10 \mathrm{mM}$ each dNTP mix (Fermentas), $0.25 \mu 1$ of $5 \mathrm{U} / \mu 1$ of DreamTaq DNA polymerase (Fermentas), $1 \mu 1$ (10 pmoles) of each of forward and reverse primer and $9.95 \mu 1$ of nuclease free water. Amplified PCR product was then quantified on $1.2 \%$ agarose gel. Amplified fragments of non-coding trnL-F region were sequenced from commercial sequencing service 'Chromous Biotech Private Limited', Bangalore, Karnataka. Sequence editing and contig generation was completed using Bioedit tool. Sequence alignment and phylogenetic tree construction based on Parsimony analyses of all the species was conducted using MEGA $\mathrm{X}$ (Version 10.0.4).

Table 1: GeneBank accessions of Potatoe species

\section{RESULT AND DISCUSSION:}

Length of amplified region of non-coding trnL-trnF fragments from Leptostemonum species was in the range 500 to $600 \mathrm{bp}$. Phylogenetic tree of five species based on trnL-trnFintergenic spacer region under Subgenus Leptostemonum viz. Solanum anguivi, Solanum khasianum, Solanum macranthum, Solanum virginianum and Solanum melongena (Sungro No. 801) and out-group Potatoe species gave a resolved analysis of species (Fig. 1). Parsimony analysis of these species data resulted into generation of phylogenetic tree which was divided into two major clades. Clade I was represented by clustering of all the species of subgenus Leptostemonum. Clade I was then further divided into two sub-clades. Sub-clade I was represented by $S$. anguivi, $S$. virginianum, $S$. macranthum along with the cultivated variety $S$. melongena (Sungro No. 801), However sub-clade II was represented by $S$. khasianum only forming the basal lineage. Clade II brought all species from Subgenus Potatoe together. Clade II was also further divided into two sub-clades. Sub-clade I was represented by $S$. muricata alone; whereas sub-clade II was uniting S. seaforthianum, S. tuberosum and $S$. bulbocastanum together.

Chloroplast genes and non-coding regions have been extensively used to reconstruct the phylogeny of related species. When compared to coding DNA region, variations of non-coding DNA regions was considered to be more helpful for phylogenetic analysis (Borsch and Quandt, 2009). In the present study, sequence data from non-coding trnL-trnF region emerged as a phylogenetically informative character. Two major clades noticeably separated two subgenera. Within clade I of subgenus leptostemonum, sub-clade I brought $S$. melongena and S. macranthum together. S. khasianum was separated from all other four species $S$. anguivi, $S$. macranthum and $S$. virginianum along with cultivated S. melongena, forming a sub-clade II alone. Formation of this sub-clade with separation of $S$. khasianum as a basal lineage is well supported with the findings of Hidayat, et al., (2016) on the basis of ITS sequence data set. Closeness of $S$. anguivi and S. melongena in this sub-clade is also in tune with the investigation of Vorontsova, et. al., (2013) as they accounted the same relation on the basis of ITS sequence data. This indicates that $S$. melongena and $S$. anguivi are more closely related with each other; however they are equally distant from S. virginianum.

As the species under subgenus Potatoe exhibit the clear separation, this is an indicative of genomic distances between these clearly indicates the separation of species from these two sub-genus under investigation. All the species from subgenus Potatoe were differentiated from the Clade-I of subgenus Leptostemonum to form a separate CladeII grouping all the related species together. This states that molecular data set of trnL-F region determines the genetic closeness. While studying 
genus Solanum, Olmstead and Palmer (1997) also separated these two subgenera on the basis of chloroplast restriction site data. While studying a three gene phylogeny of Solanaceae species from Leptostemonum and Potatoe subgenus, Weese and Bohs (2007) clearly indicated the separation of these two subgenera. Findings of previous research are in good congruence with the data generated by trnL-F intergenic spacer region data in current study.

\section{CONCLUSION:}

Although a relatively vigorous understanding of the major genera within Solanaceae exists, it is interested to note that if the sample population is more then phylogenetic inference was found to be poor. As indicated by present investigation after utilizing non-coding trnL-F data, it generate advocacy towards the utilization of this region to discriminate the species under same genus. Moreover, combined data set from coding and noncoding regions of species can also provide robust analysis for separation of closely related species as well as varieties.

\section{REFERANCE :}

Anderson G. J., Bernardello G., Bohs L., Weese T. and SantosGuerra A. (2006): Phylogeny and biogeography of the Canarian Solanum vespertilio and S. lidii (Solanaceae). Analesdel Jardın Botanico de Madrid. Vol 63: Pp 159167.

Aubriot X., Singh P., Knapp S. (2016): Tropical asian species shows that the old world clade of "spiny Solanum" (Solanum subgenus leptostemonum pro parte: Solanaceae) is not monophyletic. Botanical Journal of the Linnean Society: Vol 181: Pp 199-223

Bakker F. T., Culham A., Gomez-Martinez R., Carvalho J., Compton J., Dawtrey R. and Gibby M., (2000): Patterns of nucleotide substitution in angiosperm cpDNAtrnL (UAA)trnF (GAA) regions, Mol. Biol. Evol. 17: Pp 1146-1155

Bohs L. (2004): A chloroplast DNA phylogeny of Solanum section Lasiocarpa. Systematic Botany.Vol 29: Pp 177-187.

Bohr, L. (2005): Major clades in Solanum based on ndhf sequences. Missouri botanical Garden Press, 104: Pp 27-49
Borsch T. and Quandt D. (2009): Mutational dynamics and phylogenetic utility of noncoding chloroplast DNA. Plant Systematics and Evolution 282: Pp 169-199

Fukuda T., Yokoyama J. and Ohashi H., (2001): Phylogeny and biogeography of the genus Lycium (Solanaceae): inferences from chloroplast DNA sequences, Mol. Phylogenet. Evol.Vol 19: Pp 246-258.

Hidayat T, Priyandoko D., Islami, K.D. and Wardiny Y. P. (2016): Molecular phylogenetic analysis of Indonesia Solanaceae based on DNA sequences of internal transcribed spacer region. AIP Conference Proceedings. 1708; Pp 1-5.

Holt S.D., Horová L. and Bures P. (2004): Indel patterns of the plastid DNA trnL- trnF region within the genus Poa (Poaceae). J Plant Res. Vol 117(5): Pp 393-407.

Linneaus C. (1753): Species plantarum. ImpensisLaurentiiSalvii, Stockholm

Olmstead R.G. and Palmer J.D. (1997): Implications for the phylogeny, classification and biogeography of Solanum from cpDNArestriction site variation. N Systematic Botany. 22: Pp19-29.

Rachel L. A., Myers M. R., and Bohs L. (2006): Phylogenetic relationships among the "spiny Solanums" (Solanum subgenus leptostemonum, Solanaceae). American Journal of Botany 93(1): Pp 157-169.

Taberlet P., Gielly L., Pautou G. and Bouvet J. (1991): Universal primers for amplification of three non-coding regions of chloroplast DNA. Plant Molecular Biology, Vol 17 (5): Pp 11051109

Vorontsova M.S. and Knapp S. (2012): A new species of Solanum (Solanaceae) from South Africa related to the cultivated eggplant. PhytoKeys. (8): Pp1-11.

Vorontsova M. S., Stern S. S., Bohs L. and Knapp S. (2013): African spiny Solanum (subgenus Leptostemonum, Solanaceae): a thorny phylogenetic tangle. Bot J Linn Soc. Vol 173: Pp 176-193.

Weese T.L. and Bohs L. (2007): A three-gene phylogeny of the genus Solanum (Solanaceae). Syst Bot. 32: Pp 445-463. 
Table 1: GeneBank accessions of Potatoe species

\begin{tabular}{|c|c|c|c|}
\hline Sr. No. & Species & GenBank accession & Subgenus \\
\hline 1. & Solanum seaforthianum & DQ180438.1 & Potatoe \\
\hline 2. & Solanum tuberosum & HM006842 & Potatoe \\
\hline 3. & Solanum bulbocastanum & DQ180444 & Potatoe \\
\hline 4. & Solanum muricatum & DQ180469 & Potatoe \\
\hline
\end{tabular}

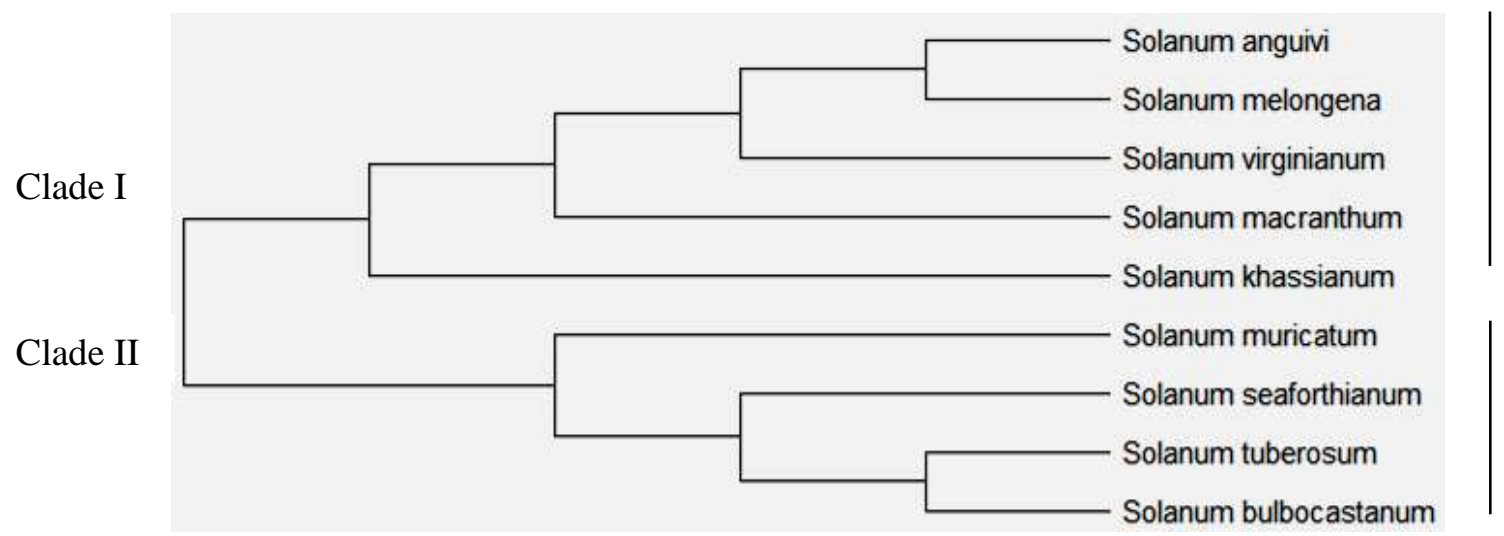

Figure 1: Phylogenetic tree of nine Solanum species based on maximum parsimony analysis based of trnL-F sequences 